\title{
THE IDEOLOGY OF LIBERALISM AND SOCIALISM IN THE CONTEXT OF CARDINAL STEFAN WYSZYŃSKI'S PERSONALIST CONCEPT OF SOCIAL LIFE
}

DOI: http://dx.doi.org/10.12775/TiCz.2021.027

\begin{abstract}
The article presents Stefan Wyszyński's personalist concept of social life in the context of the ideology of liberal capitalism and the ideological conceptions rooted in socialist ideas. The main aim of these analyses is to portray the above systems not as much in antinomic as in analogous terms. Liberal ideology and the related capitalism arose in the mid-19th century and have constantly evolved since then, often changing their main features. Socialist ideology, on the other hand, was formed as a concept opposed to the capitalist reality of the 19th century. However, it never truly existed in a particular form, and the system described as "socialism" was, in fact, a hybrid of liberal-capitalist ideas and - to a degree - a neo-feudal bureaucracy. A more detailed analysis of the above doctrines and their critical reinterpretation in the context of Wyszyński's personalist thought reveals and highlights the dangers associated with the ideologically motivated promotion of extreme, often distorted concepts of the human person and their application in the specific realities of the contemporary world.
\end{abstract}

Keywords: ideology; liberalism; socialism; personalism; Stefan Wyszyński; anthropological error; "common good".

Streszczenie. Ideologia liberalizmu i socjalizmu w kontekście personalistycznej koncepcji życia społecznego Stefana Wyszyńskiego. Prezentowany artykuł ukazuje 
personalistyczną koncepcję życia społecznego w ujęciu Stefana Wyszyńskiego w kontekście ideologii liberalnego kapitalizmu i ideologicznych koncepcji nawiązujących do idei socjalistycznych. Wiodącą tezą niniejszych analiz jest ukazanie powyższych systemów nie tyle w kategoriach antynomicznych, czy analogicznych. Ideologia liberalna i związany z nią kapitalizm powstały w połowie XIX wieku i od tego czasu nieustannie ewoluowały, często zmieniając swoje główne parametry i specyfikę. Z drugiej strony, ideologia socjalistyczna ukształtowała się jako koncepcja przeciwna kapitalistycznej rzeczywistości XIX wieku. Jednak nigdy tak naprawdę nie istniała ona w jednolitej formie. Analizowana ideologia, określana jako doktryna socjalistyczna, była w istocie hybrydą idei liberalno-kapitalistycznych i - poniekąd - neofeudalnej biurokracji. Bardziej szczegółowa analiza powyższych koncepcji i ich krytyczna reinterpretacja w kontekście myśli personalistycznej Wyszyńskiego pozwala uświadomić niebezpieczeństwa związane z motywowanym ideologicznie propagowaniem skrajnych, często zafałszowanych koncepcji osoby ludzkiej i ich zastosowaniem w konkretnych realiach współczesnego świata.

Słowa kluczowe: ideologia; liberalizm; socjalizm; personalizm; Stefan Wyszyński; błąd antropologiczny; „dobro wspólne”.

\section{INTRODUCTION}

Catholic social teaching has never intended to create a "third way" between liberal capitalism and all kinds of socialist systems. However, throughout its long history, the Church has coexisted with various models of political orders. These days, too, she tries to do so based on the fundamental principles of Christian ethics. Thus, the Church fulfills her prophetic function in the modern world, in which she considers it obligatory to look analytically at the current and proposed models of public life. Therefore, a critical analysis of socio-political systems is essential.

Cardinal Wyszyński spoke in a similar vein. Although he saw the need to change the structures of public life, he did not consider it a primary and urgent task of the Church. He also did not feel that he was called to change the state system. His criticism of the systemic issues in post-war Poland mainly concerned the anthropological and moral dimensions and aspects. However, Wyszyński realized that those crucial elements of the state's political system would undoubtedly change if there were a proper moral order in place. He repeatedly spoke of a "social disposition" that would favor a just and well-grounded social change. In his opinion, social disposition should be based on the foundation of the Christian religion, 
the aim of which is to transform the human heart (metanoia). In this way, the transformed people would become the right subject and base for the proper development of the common good. ${ }^{1}$

In Wyszyński’s teaching, however, one can also perceive a criticism of liberal capitalism understood mainly in terms of the so-called "comprador capitalism." In the present day, many critics of liberal concepts emphasize that classical liberal capitalism is fundamentally incompatible with modern economic programs as well as the so-called "planetary" ecosystem. ${ }^{2}$ Therefore, if the laws of nature cannot be changed, the approach to fundamental issues related to world politics and economy must be thoroughly revised. In practice, this means debunking the most critical "myths" rooted in the current economic and political systems based on the principles of liberal capitalism. ${ }^{3}$

When he spoke of the so-called "incomplete" systemic concepts, Cardinal Wyszyński meant not only liberal capitalism (especially in its earliest "comprador" form), but also, and above all, materialist collectivism in the Marxist-Leninist version. According to him, of course, both systems had turned out to be ineffective to varying degrees. ${ }^{4}$ In other words, neither of the systems with their different political and economic concepts had met the hopes and expectations of society. "The fact that communist states based their economy on the capitalist labor system is simply the fruit of a derivative of collectivism and capitalism. This is their original sin. For both systems stem from the same materialistic philosophy, both practically proclaim the priority of things over the person - and both fail to effectively defend man against the demon of technocratism that has put itself at the service of economics against the rights of the human person."

${ }^{1}$ Cf. S. Wyszyński, “Czas to miłość. Podczas uroczystości Wniebowzięcia Matki Bożej, Jasna Góra, 15.08.1979," in: idem, Nauczanie społeczne 1946-1981, Warzaw 1990, pp. 889-891.

2 Cf. S.E. van der Leeuw, "Climate and Society: Lessons from the Past 10,000 Years," AMBIO: A Journal of the Human Environment 37 (2008), pp. 476-482.

3 S. Wyszyński, "Moc żywej wiary w ciężkiej sytuacji Kościoła. Do duchowieństwa w Gdańsku, 23.11.1960”, in: Nauczanie społeczne, p. 166.

${ }^{4}$ Idem, "Nasze dezyderaty. Do profesorów katolickiej nauki społecznej, Jasna Góra, 22.01.1963," in: Nauczanie społeczne, p. 196.

${ }^{5}$ Idem, "Problem pracy górników w Polsce. List do księdza biskupa Herberta Bednorza, 2.02.1978," in: Nauczanie społeczne, pp. 810-811. 
Thus, a slightly closer look at the radical and "incomplete" ideologies determining the fundamental doctrines of contemporary social life allows one to better understand the vulnerability of modern ideological systems and the elements falsifying the above concepts. ${ }^{6}$

\section{IDEOLOGICAL CIRCUMSTANCES: SPECIFICITY, DIVERSITY, AND UNIFORMITY}

Ideology is any set of ordered views - religious, political, legal, natural, artistic, philosophical, etc. - serving people with the same ideas to explain the world around them. The social function of ideology is to articulate the goals of the activity and acceptable ways of achieving them and to motivate their legitimacy with considerations deemed higher than individual interest. In other words, ideology is related to a vision of reality, a coherent system of values and directives that condition practical actions. Thus, the demand for ideologies results from people's proper search for answers to questions about the meaning and mode of existence. Therefore, ideologies are normative because they propose a particular worldview, an image of the environment that motivates a set of beliefs, actions, etc. Many modern analysts argue that ideology is nothing but a "coherent system of ideas" based on fundamental assumptions about reality. However, the above ideas may or may not have any verification of objective truth. The most crucial issue here is that concepts become coherent, repeatedly reproduced patterns of behavior confirmed by subjective, current and binding choices made by particular social groups. The above ideas serve as inspiration to shape the concept and strategy of operation. ${ }^{7}$

In this context, belief in an ideology can range from passive acceptance to passionate advocacy and implacable commitment to a given ideological system. According to the latest analyses, ideologies can be completely ambivalent in the broad public perception. From an ethical point

${ }^{6}$ Idem, “Moc żywej wiary,” p. 167.

7 Cf. P. James, M. B. Steger, "Introduction," in: P. James, M. B. Steger (eds.), Globalization and Culture, Vol. 4, Ideologies of Globalism, Los Angeles-London 2010, pp. IX-XXXI. 
of view, they do not have to be good or bad. ${ }^{8}$ As Wyszyński put it, "the fact that communist states based their economy on the capitalist labor system is simply the fruit of a derivative of collectivism and capitalism. This is their original sin. For both systems stem from the same materialistic philosophy, both practically proclaim the priority of things over the person - and both fail to effectively defend man against the demon of technocratism that has put itself at the service of economics against the rights of the human person." In other words, the personalist social thought represented by Wyszyński offers a broader and more critical view of the methodology defined by contemporary socio-political doctrines. Moreover, the above concept is more in line with the conditions determining the complex system of a market economy. ${ }^{10}$

Of course, Christian personalism considers social diversity a natural and essential factor in social development. However, it does so not because the above factor promotes "productivism" and the activity of the most talented individuals, but rather for the good of society as a whole. ${ }^{11}$ However, people who are poor and, for various reasons, unfit to compete in the labor market should be the object of concern of the whole society, especially its most affluent part. For Christians, material goods are a gift of Providence that comes with commitment and responsibility. Therefore, they cannot indeed be regarded as a purely personal merit. ${ }^{12}$

\section{LIBERALISM: PARADIGM AND REALITY}

The central theme of liberal ideology is the emphasis on the role of the individual and the desire to build a society in which people will be able to satisfy their own interests and thus achieve their fulfillment. Liberals believe that humans are, first and foremost, individuals endowed with reason and free will. Therefore, they have the right, and even the duty, to

${ }^{8}$ Cf. K. Mannheim, Ideologie und Utopie, Mannheim 2015.

9 S. Wyszyński, “Problem pracy górników”, pp. 810-811.

10 Cf. R. Ficek, "Collectivism, Individualism, and Cardinal Stefan Wyszyński’s Personalistic Concept of Man," Roczniki Nauk Społecznych 12/48 (2020) no. 1, pp. 5-32.

11 Cf. S. Wyszyński, "Czas to miłość," pp. 889-891.

12 Cf. S. Wyszyński, “Homo oeconomicus," in: Nauczanie społeczne, pp. 582-585. 
decide their own lives. Despite equal social and political rights, people should be rewarded according to their personal talents and willingness to work in specific cases. In a socio-political sense, however, liberal societies are organized around a paradigm of fundamental constitutionalism and social consent, designed to protect citizens from the dangers of authoritarianism and government tyranny. In other words, classical liberalism was an apotheosis of social and economic freedom - understood as freedom in economic activity, unhampered individual entrepreneurship. Also, freedom of exchange is aimed at maximizing profits and pursuing one's interests. In this sense, liberalism has been equated with the economic efficiency and prosperity that societies can achieve through costeffective freedom, hard work and competition. ${ }^{13}$

Of course, liberalism is not a homogeneous doctrine. What is more, it has changed its face very clearly over the last two hundred years. This statement applies to philosophical and social liberalism as well as to economic liberalism, which found its concrete expression in classical capitalism and its modern variants (including neo-capitalism). The most critical flagships with which this system is associated are freedom, equality, property, laissez-faire, freedom of action, freedom for enterprises, freedom of exchange, free movement of capital, people and goods, free market, limitation of state intervention, etc. The ideas of liberalism - such as freedom, individualism, evolution - very quickly embraced new areas of human existence: the worldview, social, political and state, economic, spiritual and cultural as well as religious or Church and political spheres. However, liberal views crystallized to the fullest extent and then found their application in political and economic life.

Nevertheless, the 19th century was, in many ways, a period dominated by liberal ideology. As industrialization spread to Western countries, liberal ideas triumphed. Moreover, liberals advocated an industrialized and market-based economic order "free" from government interference in which enterprises could seek profit. States were encouraged to trade freely among themselves. This type of industrial capitalists system first developed in Britain in the mid-18th century and then spread to North America and all of Europe. In the twentieth century, industrial capital-

13 Cf. P. Berkowitz, Virtue and the Making of Modern Liberalism, Princeton 2000, pp. 184-188. 
ism strongly appealed to developing countries in Africa, Asia and Latin America, primarily when social and political development was defined essentially in Western terms. However, the so-called "developing" countries often rejected the attractiveness of liberal capitalism because their political cultures emphasized the community, not the individual. In such cases, they provided a more fertile ground for the growth of socialism, nationalism or religious fundamentalism than Western liberalism.

Current political systems that draw from liberalism include a wide range of competing concepts. These encompass the "Chicago school," ${ }^{14}$ the "Austrian school,"15 "Public Choice Theory,"16 "institutional economics," monetarism, ${ }^{18}$ "Keynesianism," 19 "Georgism," ${ }^{20}$ distributionism, ${ }^{21}$ socialism $^{22}$ and other economic concepts related to the above ideas. Nevertheless, in common understanding, the issues of political and economic liberalism are classified in terms of "neoclassical theory." In other words, they refer to classical capitalist ideas, usually associated with the concepts of Adam Smith, David Ricardo or other ideologists of the system from the 19th and early 20th centuries. Presenting the above ideas in the light of the current political and economic conditions as well as the fun-

14 Cf. R.B. Emmett, The Elgar Companion to the Chicago School of Economics, Cheltenham 2010.

${ }^{15}$ Cf. H. Hagemann, T. Nishizawa, Y. Ikeda, Austrian Economics in Transition: From Carl Menger to Friedrich Hayek, London-New York 2010.

16 Cf. S. Behrends, Neue Politische Ökonomie. Systematische Darstellung und kritische Beurteilung ihrer Entwicklungslinien, Munich 2001; R.G. Holcombe, "The Median Voter Model in Public Choice Theory," Public Choice 61 (1989), pp. 115-125.

17 Cf. K.W. Kapp, The Foundations of Institutional Economics, London-New York 2011.

18 Cf. J.K. Galbraith, "Das Scheitern des Monetarismus. Von den Theorien Milton Friedmans zur Weltfinanzkrise," Blätter für deutsche und internationale Politik 9 (2008), pp. 69-80.

19 Cf. R. Dimand, The Origins of the Keynesian Revolution, Aldershot 1988; R. J. Gordon, "What Is New-Keynesian Economics?, Journal of Economic Literature 28 (1990) no. 3, pp. 1115-1171.

${ }^{20}$ Cf. Council of Georgist Organizations, An Introduction to Georgist Philosophy and Activity, http://www.cgocouncil.org/cwho.html (retrieved on December 9, 2019).

${ }^{21}$ Cf. D. W. Cooney, "Distributism Basics: A Brief Introduction," in: Ethika Politika, https://ethikapolitika.org/2014/08/08/distributism/ (retrieved on December 9, 2019).

22 Cf. P. Wilberg, Deep Socialism: A New Manifesto of Marxist Ethics and Economics, London 2003, pp. 3-38; R. Pipes, Property and Freedom, New York 2000, pp. 209-281. 
damental concepts of Christianity referring to the thought of St. Thomas of Aquinas or Aristotle is essential in the context of such vital issues as social justice or the idea of social solidarity. ${ }^{23}$ It is not surprising, then, that the personalist vision of social life as understood by Wyszyński emphasizes the need to show the meaning of and co-relationship between social justice and economic justice. The concept of social justice is deeply rooted in the idea of human dignity, which in turn seems to undermine the legalistic logic of property rights, the distribution of goods and the contemporary political and economic relations that condition the idea of economic justice. $^{24}$

In view of the above, an essential factor in involvement in the economy is part of the contemporary concept of justice in public life, but often violates social justice. ${ }^{25}$ In this sense, it is essential to make appropriate changes to the liberal economic system and make people aware that many of the achievements of the so-called liberal "market economy" result from non-economic factors. Moreover, economics as a scientific discipline needs an axiological orientation (that is, an orientation based on moral values). It requires the valuation of the dignity of the primary subject of economic activity, which is man in the dimension of his dignity rather than the ontically simplified and diminished homo oeconomicus. ${ }^{26}$ By exposing this issue, the concept of social life presented by Wyszyński's personalism points to the achievements of not only Thomistic but also personalist thought. This is crucial now when social sciences - emphasizing the broadly understood "humanitarianism" - distance themselves from the idea of love and mercy as an essential principle of social life. Moreover, the concept of love and mercy does not find practical recognition in contemporary sociological theories. It is of insufficient importance in today's psychology as well as in modern economic systems. Undoubt-

${ }^{23}$ Cf. G. Small, "Connecting Economics to Theology," Solidarity: The Journal of Catholic Social Thought and Secular Ethics 1 (2011) no. 1, pp. 1-2.

${ }^{24}$ Cf. R. Ficek, "Love, Mercy and Social Justice in the Context of Cardinal Stefan Wyszyński's Personalist Concept of Social Life," Collectanea Theologica 91 (2021) no. 1, pp. 103-108.

25 Cf. J. Perkins, Confessions of an Economic Hit Man, San Francisco 2004. Oxford 1981.

${ }^{26}$ Cf. A.K. Sen, Poverty and Famines: An Essay on Entitlement and Deprivation, 
edly, both Thomism and personalism are based on the idea of love and mercy as the foundation for other social principles. ${ }^{27}$

Cardinal Wyszyński was aware of this. In his teaching, he often mentioned "social dispositions" rooted in the Christian system of values which should stimulate and shape both the socio-political transformation and the economic transformation of the earthly reality. In other words, the social order based on the personalist system leads to the transformation of the human person, both individually and socially. Therefore, only moral change directed at a mature personality is a condition for the proper modification of all structures of public life and a basis for building the "common good" of the whole society. ${ }^{28}$ However, one must take into account that liberalism - and above all liberal capitalism as an ideology in its diversity - is a concept that is quite difficult to define. In practice, the term "liberal capitalism" refers to the widely differing systems that characterize a market economy. This concept includes the so-called "welfare capitalism" typical of contemporary liberal Western democracies, the "comprador" capitalism based on political clientele (crony capitalism) and the "kleptocratic" capitalist systems that often characterize corrupt Third World countries (kleptocracy). The classic form of the capitalist system as depicted by thinkers such as Adam Smith, David Ricardo, Thomas Malthus or John Stuart Mill is only a theoretical model. ${ }^{29}$

However, concern for the poor and those in need also stems from political pragmatism. Excessive social inequalities always lead to antagonism and social unrest. Consequently, they are a severe threat to the entire society. In that respect, the counterpart of homo oeconomicus is economism, which reduces all social relations to the logic of a market economy. In this sense, economism is treated by many representatives of liberalism as an ideology characterized by a certain kind of faith, like a quasi-religious system. In their opinion, cultivating this kind of "modern" religion is very important for the functioning of the global market economy, justifying personal decisions, legitimizing many "morally questionable" mar-

27 Cf. R. Ficek, “Love, Mercy and Social Justice," pp. 112-126.

28 S. Wyszyński, "Problem pracy górników, pp. 810-811.

29 Cf. R. Ficek, Christians in Socio-Political Life: An Applied Analysis of the Theological Anthropology of Cardinal Stefan Wyszyński, Primate of Poland, Torun 2020, pp. 107-121; J. Bartyzel, W gaszczu liberalizmów. Próba periodyzacji i klasyfikacji, Lublin 2004. 
keting strategies and explaining and rationalizing the world as a "global village" in which the rules are created by a global system of the world economy. Incidentally, "economism" often tries to enter into a syncretic relationship with institutionalized religion, even though it repeatedly violates its essential principles. ${ }^{30}$ Of course, "economism" understood in globalist categories uses the language of its ideology, for which the main task is "the good of all humanity" understood in a particular way. This kind of "uncriticized" economic credo - often treated as an unquestionable dogma of modern times - has been transferred to other areas of social life, including, above all, ecology. It is imperative now, when "adherents" of ecology are increasingly trying to use socio-economic phraseology to rationalize their actions to protect the entire ecosystem for which man seems to be the greatest threat.

\section{SOCIALISM: THE CONCEPT AND ITS APPLICATIONS}

The socialist (collectivist) concept of man is different from individualist-liberal anthropology, especially its very specific variant: the "Nazi National Socialism." It is worth noting that the above ideology became the official program of the Nazi National Socialist party (NSDAP). Thus, it laid the theoretical foundations for the Nazi strategy of military expansion that led to the terrible hecatomb of World War II. ${ }^{31}$ The vision of human life presented by the ideologues of the Third Reich, especially concerning "racially inferior" communities, is terrifying. A characteristic feature of the above ideology was, above all, an aversion to all kinds of personalist values, both intellectual and moral, especially in the Christian version. ${ }^{32}$

In response to many shortcomings relating, in particular, to classical capitalism, many alternative political and economic systems with a socialist origin emerged. One of them was classical communism, developed mainly by Karl Marx and Friedrich Engels and modified by Vladimir

30 Cf. P. Berkowitz, "Virtue and the Making of Modern Liberalism," pp. 15-22.

31 Cf. S. Wyszyński, Miłość i sprawiedliwość społeczna. Rozważania społeczne, Poznań 1993, p. 47; R. Paxton, The Anatomy of Fascism, London 2005; D. Redles, Hitler's Millennial Reich: Apocalyptic Belief and the Search for Salvation, New York 2005.

32 Cf. S. Wyszyński, Miłość i sprawiedliwość, p. 47. 
Lenin. ${ }^{33}$ The above system was the subject of a particularly intensive analysis carried out by Wyszyński. For most of his life, the Primate of Poland had to face the Marxist concept of an atheist communist system that fought not only against God, but also - and perhaps above all - against man. ${ }^{34}$ The very term "socialism" is used to oppose individualism. Socialism referred to the communal rather than individual aspect of human existence, which had its reasons and justifications - not only theoretical, but also practical. The popularity of socialist ideology was related mainly to opposition to the increasingly aggressive, individualist "comprador" capitalism, the rationalist "school of natural law," which seemed too abstract, not very empirical, and therefore not practical for the average person. In this context, according to this concept, freedom is limited only by the binding, statutory law - disregarding somehow morality (since natural law is a non-statutory reality). This theoretical situation continues today, albeit in a milder form (e.g., human rights). And yet the law can be immoral, has gaps, is subject to various interpretations, is imposed under the pressure of immediate needs, is the result of multiple compromises, etc. It is not surprising, then, that in his reflection on the critique of MarxismLeninism and the communist vision of social life, Cardinal Wyszyński states that the fundamental error of socialism is an anthropological issue. Therefore, in his opinion, the entire point of the personalist concept of social life is the integral vision of the human person, which is the basis for the existence and functioning of all social structures. ${ }^{35}$

Following the Hegelian and Marxist tradition, social philosophy held that knowing the truth, or proper knowledge, presupposes action leading to its realization; therefore, theory and practice are only two sides of the same process. This belief marked the Hegelian thesis that what is real is real and what is real is true. At the same time, the problem that is associated with the ontological and epistemological position characterized above is that the idea of absolute and total power (strength) appears

33 Cf. M. Bloch, Marxism and Anthropology, New York 2010.

${ }^{34}$ Cf. S. Wyszyński, Miłość i sprawiedliwość, pp. 46-47.

35 Cf. idem, "Społeczność przyrodzona i nadprzyrodzona. II Konferencja Akademicka. Warszawa - kościół św. Anny, 16.02.1957,” in: Kazania i przemówienia autoryzowane 1956-1981, vol. 1-67. Archiwum Instytutu Prymasowskiego w Warszawie, vol. 2, p. 61. 
along with the idiom of complete knowledge, and thus, absolute control serving to realize or maintain a "true vision" of reality. The above theory also implies a single goal for society as a whole, leading to the rejection of the other purpose of seeking objective truth. This is because it is already "given" in the form of an ideology and thus maintains an artificial social order in place of a spontaneous one that results from the nature of things. However, the ultimate goal and task of the adherents of such a theory is not to understand reality - especially social reality based on what it is but to revolutionize it. This thesis expressed by Marx became the basis of the communist doctrine. ${ }^{36}$

In the context of personalist philosophy, emphasizing the issue of man, emphasizing his personal dignity - both in the natural and supernatural dimension - shows the unquestionable preeminence he has in all social, cultural, economic and political life. In other words, man is the principle, subject and goal of all social devices. ${ }^{37} \mathrm{~A}$ specific ontic position - characteristic only of man - determines his functioning in the social reality and determines his proper place in the entire ontic structure. ${ }^{38}$ Therefore, it comes as no surprise that Wyszyński strongly opposed the Marxist-Leninist materialist ideology and considered it the greatest danger to Christianity. As an ideology that spreads a materialistic vision of the human person and social life, it was deemed hostile to the Christian aspirations of promoting respect for human dignity and shaping the Christian social order. Moreover, materialism denies the existence of any spiritual dimension in social life. Thus, it is a progressive deviation from a supernatural, spiritual and religious reality that only recognizes facts which can be grasped by sensory experience; it does so to blind people and thus dissuade them from supernatural and eternal existence. ${ }^{39}$

In Christian personalism, however, the human person - the integral unity of matter and spirit that creates the personality subject of human action - expresses his attitude towards the world, which boils down

${ }^{36}$ Cf. D. Pietrzyk-Reeves, "Błąd antropologiczny komunizmu i odwrót od polityki," in: Totalltaryzm a zachodnia tradycja, M. Kuniński (ed.), Kraków 2016, p. 102.

37 Cf. Gaudium et spes, sec. 25.

38 Cf. S. Wyszyński, "O katolickiej woli życia. List pasterski na Wielkanoc 1947," in: Nauczanie społeczne, pp. 34-36.

39 Cf. R. Ficek, Christians in Socio-Political Life, pp. 157-162. 
to multiple and complicated relations with the surrounding social reality. However, none of them can fully satisfy the complex and varied needs except a proper relationship with another human being as an individual and a community. This openness determines the potentiality of human existence as well as the ability and possibility of its development, transcendence, and achievement of personal fulfillment. ${ }^{40}$ Moreover, "man's life is the beginning, announcement, and condition of other gifts - temporal and eternal." ${ }^{41}$ Therefore, the spiritual-corporeal nature of a human being, expressed in his free and rational action, is a constitutive quality of man. Therefore, the human person is one thing, permanent, integrated, despite the ontological composition, and at the same time, he is a unifying being and integrates with himself numerous activities and features as their subject, substrate and cause. The spiritual element in man fulfills the role of a visible sign of God's closeness to the material world. A human person connects with the surrounding world through his body because he is a part of it. He lives and acts in it, is subject to its laws, and occupies a unique position. He is its master: he organizes it, masters it, transforms it, and uses it for his life and development. As a material element, the body is also a bridge connecting the reality of the material world with the transcendental dimension, that is, with God Himself. ${ }^{42}$

\section{IN SEARCH OF AN "OTHER WAY"}

The distorted vision of the world and the human person not only deprives man of an essential spiritual sphere, but also reduces him to the level of a typical product of the material world. It distorts the basic dimensions of human life, preventing man from fully realizing his needs and goals. ${ }^{43}$ Criticism of the so-called "incomplete systems" made by

40 Cf. S. Wyszyński, "Homo Dei, I kazanie świętokrzyskie, 13.01.1974," in: Nauczanie społeczne, pp. 576; W. Gałkowski, “Być czy mieć?”, Ethos 3 (1990) no. 11-12, pp. 328.

${ }^{41}$ S. Wyszyński, "W obronie życia nienarodzonych," in: Listy Pasterskie Episkopatu Polski 1945-1974, Paris 1975, p. 118.

42 Cf. S. Wyszyński, "Uświęcenie doczesności. Do duchowieństwa Warszawy, 3.08.1962," in: Nauczanie społeczne, p. 193.

${ }^{43}$ Cf. S. Wyszyński, "Duch Boży w wolnym człowieku. Podczas bierzmowania młodzieży akademickiej w Warszawie, 19.05.1977," in: Nauczanie społeczne, pp. 779-780; 
Wyszyński was primarily aimed at defining the basic principles on which the involvement of Christians in the social and political reality should be built. Of course, in his analysis of the liberal-capitalist and collectivist model of social life, the Primate referred to the teachings of the popes and the Church's Magisterium. In his opinion, the above systems negated the basic ideas of the Christian vision of social and political life as well as the subjectivity of the members of the state community. Despite its undoubted advantages, liberal capitalism did not contribute to the liberation of citizens, either, because "man is not yet respected. He is still a slave, of the state, then of the matter again." 4

In the personalist vision of social life advocated by Wyszyński, several essential primary identifiers of criticism of both the capitalist system and socialism should be distinguished. They indicate attitudes and values required to maintain the Christian moral and social order, threatened by liberal capitalism and socialist ideology. Among them, we can distinguish human rights, including the right to a dignified life, as well as responsibility for social life. However, the most severe accusation against both liberal and socialist ideology - especially in the Marxist-Leninist version - pertained to the wrong conception of the human person. ${ }^{45}$

According to the Primate, economic progress conditioned by liberalism and the classical capitalism that grew on its basis, as well as collectivism, should be subject to human authority. Therefore, it is impossible to accept the accumulation of vast means of production and leave them arbitrarily to a narrow group of political and economic system beneficiaries. In Wyszyński’s view, man is the beginning and goal of social life thanks to his societal nature. And although he needs a family, state, cultural, religious and economic community for his development, he goes beyond its limits due to the unusual structure of life. ${ }^{46}$ According to Primate Wyszyński, "in our socio-political thinking, we must always main-

cf. S. Jarocki, “Kultura gospodarcza," Ateneum Kapłańskie 62 (1970) no. 75, pp. 240-247; R. Ficek, Christians in Socio-Political Life, pp. 176-182.

${ }^{44}$ Cf. S. Wyszyński, "Nasze dezyderaty," p. 197.

${ }^{45}$ Cf. idem, "Duch Ewangelii w organizacji życia społeczno-zawodowego i publicznego w Polsce," in: Nauczanie społeczne, p. 808.

${ }^{46}$ Cf. idem, "Kościół jest najlepszym sprzymierzeńcem waszych dążeń. Do NSZZ „Solidarnośćc regionu Wielkopolska, Gniezno 4.02.1981," in: idem, Do „Solidarności”, Warsaw 1996, p. 50. 
tain the superiority of man [...] even if he was born in the 20th or the next century, he has existed in God's thoughts and plans for centuries. That is why man came into existence earlier than any family, national or state community." 47

A personalist vision of involvement in socio-economic life, involving a mysterious synthesis of suffering and joy, reflects the age-old dichotomy of grace and sin. It becomes a dramatic struggle that brings satisfaction and happiness and, at the same time, causes toil, anguish and suffering. Although it is expressed in various forms, it is an inseparable element of all human activity. Securing the "common good," i.e., the service role towards the nation and its basic social structures, is the essential task of the state, "because the state is the 'bonum commune,' the common good of the whole nation and all citizens." ${ }^{8}$ Therefore, we expect the state community to serve the common good of the entire diverse community of the country's citizens. ${ }^{49}$ The common good, however, cannot be understood solely in terms of material well-being. The above expression also includes spiritual goodness. Therefore, it cannot be reduced only to the material level, the quality of public services, nor can it be measured solely by economic or ideological parameters. Wyszyński emphasized many times that the common good contains both temporal and supernatural elements. The human person, on the other hand, has transcendental hopes and aspirations. ${ }^{50}$

The praxeological character of Primate Wyszyński's teaching means that his interest in the issues being discussed focuses primarily on the axiological and ontic transcendence of the human person. It is expressed in the relation of man to the sphere of lower values (economic or liferelated) and higher values (cognitive, moral and aesthetic). The realization of these values determines not only the proper mental and spiritual development of man but also the final achievement of the transcendent

${ }^{47}$ Idem, “Matka-Syn-rodzina, Warszawa - kościół św. Krzyża, 11.01.1976," in: Nauczanie społeczne, p. 679

48 Idem, “Naród - Kościół - Państwo. Kazanie świętokrzyskie, 25.01.1976”, in: Nauczanie społeczne, p. 713.

49 Cf. ibidem, p. 711.

50 Cf. S. Wyszyński, "Sumienie prawe u podstaw odnowy życia narodowego. Do wiernych w archikatedrze warszawskiej, 6.01.1981,” in: Nauczanie społeczne, p. 992. 
dimension of humanity, which is fully realized in God. ${ }^{51}$ This way, socio-economic life confirms the total, all-embracing and authentic human transcendence. The main goal of involvement in mortality is not limited to the socio-economic dimension. It allows man to look at his life as a gift of God that transcends the limits of mortality and reaches the perspective of "a new heaven and a new earth" (cf. Rev 4:2-8; 21:2-10).

\section{CONCLUSIONS}

The personalist concept of social life as understood by Cardinal Wyszyński was not limited solely to the criticism of political systems based either on the assumptions of capitalist ideology or on the socialist-communist collectivist doctrine, especially of Marxist-Leninist provenance. In this context, Wyszyński repeatedly spoke about socio-economic and political issues. However, he always did it through the prism of the deposit of Christian faith and morality. The main argument for this kind of aspiration was to emphasize the autonomy of earthly reality understood in terms of distancing oneself from one another.

Rooting reflection primarily in biblical revelation and Catholic social doctrine - supported by knowledge of other scientific fields as well as a good orientation in the then historical, social, economic and political changes - creates an original concept of action in public life, presenting the systemic sphere of the state as a dimension of the involvement of man in the perspective of God's economy of salvation. It is crucial, however, especially in the context of the specific socio-political situation of the country - dominated by a Marxist ideology which, by proclaiming an apparent cult of work and progress, degraded all dimensions of human activity, including man himself. On the contrary, the personalist vision of involvement in public life as described by Cardinal Wyszyński perceives human socio-economic and political action from the perspective of the mystery of God, the Church, and the events of salvation. Therefore, by collabo-

${ }^{51}$ Cf. Wyszyński, “Budowa kultury chrześcijańskiej. Do członków „Odrodzenia“ na Jasnej Górze, 15.09.1979," in: Nauczanie społeczne, pp. 895-897; idem, "Budowanie Wrocławia z żywych i wybranych kamieni. Wrocław - kościół św. Wojciecha, 15.10.1966,” in: idem, Z rozważań nad kulturq ojczysta, Warsaw 1998, pp. 104-106. 
rating in the work of creation, man participates in the creative mystery of God, additionally confirmed by Jesus Christ, who manifests Himself in the Church. In this way, man's creative involvement in earthly life becomes the plane of his meeting with the Person of Creator and Savior.

Finally, the public sphere becomes the place where the personalist world of man meets the world of matter. The conclusion is that the outcomes of human creative activity cannot be seen solely in marketing terms but are a revelation of the human person in the space of material reality. Through creative activity understood in this way, a person defines his individuality and reveals the truth about himself. The personalist outline of the teaching of Cardinal Wyszyński, emphasizing the vital dimension of human involvement in social life, is understood primarily in terms of a personal vocation that each person is endowed with. Its implementation becomes the essential task of the human person, which is of fundamental importance both in the natural and supernatural dimensions.

\section{BIBLIOGRAPHY}

Bartyzel J., W gąszczu liberalizmów. próba periodyzacji i klasyfikacji, Lublin 2004.

Behrends S., Neue Politische Ökonomie. Systematische Darstellung und kritische Beurteilung ihrer Entwicklungslinien, Munich 2001.

Berkowitz P., Virtue and the Making of Modern Liberalism, Princeton 2000.

Bloch M., Marxism and Anthropology, New York 2010.

Cooney D. W., Distributism Basics: A Brief Introduction, in: Ethika Politika, https://ethikapolitika.org/2014/08/08/distributism/ (retrieved on December 9, 2019).

Council of Georgist Organizations, An Introduction to Georgists Philosophy and Activity, http://www.cgocouncil.org/cwho.html (retrieved on December 9, 2019).

Dimand R., The Origins of the Keynesian Revolution, Aldershot 1988.

Emmett R. B., The Elgar Companion to the Chicago School of Economics, Cheltenham 2010.

Ficek R., "Collectivism, Individualism, and Cardinal Stefan Wyszyńskis Personalistic Concept of Man," Roczniki Nauk Spotecznych 12/48 (2020) no. 1, pp. 5-32.

Ficek R., "Love, Mercy and Social Justice in the Context of Cardinal Stefan Wyszyński’s Personalist Concept of Social Life," Collectanea Theologica 91 (2021) no. 1, pp. 101-132.

Ficek R., Christians in Socio-Political Life: An Applied Analysis of the Theological Anthropology of Cardinal Stefan Wyszyński, Primate of Poland, Torun 2020. 
Galbraith J. K., "Das Scheitern des Monetarismus. Von den Theorien Milton Friedmans zur Weltfinanzkrise," Blätter für deutsche und internationale Politik 9 (2008), pp. 69-80.

Gałkowski W., "Być czy mieć?," Ethos 3 (1990) no. 11-12, p. 328.

Gaudium et spes, https://www.vatican.va/archive/hist_councils/ii_vatican_council/documents/vat-ii_const_19651207_gaudium-et-spes_en.html (retrieved on December 9, 2019).

Gordon R. J., "What Is New-Keynesian Economics?" Journal of Economic Literature 28 (1990) no. 3, pp. 1115-1171.

Hagemann H., Nishizawa T., Ikeda Y., Austrian Economics in Transition: From Carl Menger to Friedrich Hayek, London-New York 2010.

Holcombe R. G., “The Median Voter Model in Public Choice Theory," Public Choice 61 (1989), pp. 115-125.

James P., Steger M. B., "Introduction,” in: P. James, M. B. Steger (eds.), Globalization and Culture, Vol. 4, Ideologies of Globalism, Los Angeles-London 2010, pp. IX-XXXI.

Jarocki S., "Kultura gospodarcza," Ateneum Kapłańskie 62 (1970) no. 75, pp. 240-247.

Kapp K. W., The Foundations of Institutional Economics, London-New York 2011.

Mannheim K., Ideologie und Utopie, Mannheim 2015.

Paxton R., The Anatomy of Fascism. London 2005.

Perkins J., Confessions of an Economic Hit Man, San Francisco 2004.

Pietrzyk-Reeves D., "Błąd antropologiczny komunizmu i odwrót od polityki", in: M. Kuniński, (ed.), Totalitaryzm a zachodnia tradycja, Kraków 2016, pp. 102-115.

Pipes R., Property and Freedom, New York 2000.

Redles D., Hitler's Millennial Reich: Apocalyptic Belief and the Search for Salvation, New York 2005.

Sen A. K., Poverty and Famines: An Essay on Entitlement and Deprivation, Oxford 1981.

Small G., "Connecting Economics to Theology," Solidarity: The Journal of Catholic Social Thought and Secular Ethics 1 (2011) no. 1, pp. 1-2.

Van der Leeuw S. E., "Climate and Society: Lessons from the Past 10,000 Years," AMBIO: A Journal of the Human Environment 37 (2008), pp. 476-482.

Wilberg P., Deep Socialism: A New Manifesto of Marxist Ethics and Economics, London 2003.

Wyszyński S., "Budowa kultury chrześcijańskiej. Do członków Odrodzenia“ na Jasnej Górze, 15.09.1979,” in: S. Wyszyński, Nauczanie społeczne 1946-1981, Warszawa 1990, pp. 893-897.

Wyszyński S., "Budowanie Wrocławia z żywych i wybranych kamieni. Wrocław - kościół św. Wojciecha, 15.10.1966,” in: S. Wyszyński, Z rozważań nad kulturą ojczysta, Warsaw 1998, pp. 101-108.

Wyszyński S., "Czas to miłość. Podczas uroczystości Wniebowzięcia Matki Bożej, Jasna Góra, 15.08.1979)," in: S. Wyszyński, Nauczanie społeczne 1946-1981, Warsaw 1990, pp. 888-892.

Wyszyński S., "Duch Boży w wolnym człowieku. Podczas bierzmowania młodzieży akademickiej w Warszawie, 19.05.1977," in: S. Wyszyński, Nauczanie społeczne 1946-1981, Warsaw 1990, pp. 778-782. 
Wyszyński S., "Duch Ewangelii w organizacji życia społeczno-zawodowego i publicznego w Polsce," in: S. Wyszyński, Nauczanie społeczne 1946-1981, Warsaw 1990, pp. 801-809.

Wyszyński S., "Homo Dei, I kazanie świętokrzyskie, 13.01.1974,” in: S. Wyszyński, Nauczanie społeczne 1946-1981, Warsaw 1990, pp. 574-580.

Wyszyński S., "Homo oeconomicus, II kazanie świętokrzyskie, 20.01.1974," in: S. Wyszyński, Nauczanie społeczne 1946-1981, Warsaw, pp. 581-588.

Wyszyński S., “Kościół jest najlepszym sprzymierzeńcem waszych dążeń. Do NSZZ „Solidarność” regionu Wielkopolska, Gniezno 4.02.1981, in: S. Wyszyński, Do „Solidarności", Warsaw 1996, p. 50.

Wyszyński S., "Matka-Syn-rodzina, Warszawa - kościół św. Krzyża, 11.01.1976”, in: S. Wyszyński, Nauczanie społeczne 1946-1981, Warsaw 1990, pp. 676-683.

Wyszyński S., "Moc żywej wiary w ciężkiej sytuacji Kościoła. Do duchowieństwa w Gdańsku, 23.11.1960," in: S. Wyszyński, Nauczanie społeczne 1946-1981, Warsaw 1990, pp. 161-167.

Wyszyński S., “Naród - Kościół - Państwo. Kazanie świętokrzyskie, 25.01.1976," in: S. Wyszyński, Nauczanie społeczne 1946-1981, Warsaw 1990, pp. 705-713.

Wyszyński S., "Nasze dezyderaty. Do profesorów katolickiej nauki społecznej, Jasna Góra, 22.01.1963," in: S. Wyszyński, Nauczanie społeczne 1946-1981, Warsaw 1990, pp. 195-200.

Wyszyński S., “O katolickiej woli życia. List pasterski na Wielkanoc 1947,” in: S. Wyszyński, Nauczanie społeczne 1946-1981, Warsaw 1990, pp. 29-40.

Wyszyński S., "Problem pracy górników w Polsce. List do księdza biskupa Herberta Bednorza, 2.02.1978," in: S. Wyszyński, Nauczanie społeczne 1946-1981, Warsaw 1990, pp. 810-814.

Wyszyński S., "Społeczność przyrodzona i nadprzyrodzona. II Konferencja Akademicka. Warszawa - kościół św. Anny, 16.02.1957,” in: Kazania i przemówienia autoryzowane 1956-1981, vol. 1-67. Archiwum Instytutu Prymasowskiego w Warszawie, vol. II, pp. 57-79.

Wyszyński S., "Sumienie prawe u podstaw odnowy życia narodowego. Do wiernych w archikatedrze warszawskiej, 6.01.1981," in: S. Wyszyński, Nauczanie społeczne 1946-1981, Warsaw 1990, pp. 986-994.

Wyszyński S., “Uświęcenie doczesności. Do duchowieństwa Warszawy, 3.08.1962," in: S. Wyszyński, Nauczanie społeczne 1946-1981, Warsaw 1990, pp. 188-194.

Wyszyński S., "W obronie życia nienarodzonych," in: Listy Pasterskie Episkopatu Polski 1945-1974, Paris 1975, pp. 147-152.

Wyszyński S., Miłość i sprawiedliwość społeczna. Rozważania społeczne, Poznań 1993. 
